\title{
The Relationship between Hemoglobin and BMI
}

\author{
Mazin S Salman ${ }^{1 *}$, Hanan Shwaish ${ }^{1}$, Mariam N Jassim ${ }^{1}$ and Wefak \\ Hasan $^{2}$ \\ ${ }^{1}$ Ministry of Education, Iraq \\ ${ }^{2}$ Ministry of Health, Iraq \\ *Corresponding Author: Mazin S Salman, Ministry of Education, Iraq.
}

Received: March 09, 2020

Published: May 08, 2020

(C) All rights are reserved by Mazin S Salman., et al.

\begin{abstract}
BMI (body mass index) and $\mathrm{Hb}$ (hemoglobin) are one of the important factors related to our life, both play a great role in the determination of human health. The aim of this research is studying the relationship between Hb and BMI. The study carried out in the out patients department and hematological laboratory of Al Sadir Teaching Hospital and measured for the patients weight, height, BMI and $\mathrm{Hb}$. Conclude that there is decreasing in the $\mathrm{Hb}$ of the obesity in all classes and this is because the obese people may include more macronutrients and less micronutrients in their diet.
\end{abstract}

Keywords: Nutrition; BMI; Hb; Body Mass Index; Hemoglobin

\section{Introduction}

$\mathrm{BMI}$ and $\mathrm{Hb}$ are one of the important factors related to our life, both play a great role in the determination of human health, the body mass index (BMI) is a value derived from the mass (weight) and height of an individual. The BMI is defined as the body mass divided by the square of the body height and is universally expressed in units of $\mathrm{kg} / \mathrm{m}^{2}$, resulting from mass in kilograms and height in meters. The BMI is an attempt to quantify the amount of tissue mass (muscle, fat, and bone) in an individual, and then categorize that person as underweight, normal weight, overweight, or obese based on that value [1]. Commonly accepted BMI ranges are underweight: less than $18.5 \mathrm{~kg} / \mathrm{m}^{2}$, normal weight: from 18.5 to under 25, overweight: 25 to under 30 , class I obesity: from 30 to under 35, class II obesity: from 35 to under 40 , class III obesity: 40 or more [2]. BMI provides a simple numeric measure of a person's thickness or thinness, allowing health professionals to discuss weight problems more objectively with their patients. BMI was designed to be used as a simple means of classifying average sedentary (physically inactive) populations, with an average body composition [3]. BMI is used differently for children. It is calculated in the same way as for adults, but then compared to typical values for other children of the same age. Instead of comparison against fixed thresholds for underweight and overweight, the BMI is compared against the percentile for children of the same sex and age [4]. A BMI that is less than the 5th percentile is considered underweight and above the 95th percentile is considered obese. Children with a BMI between the 85th and 95th percentile are considered to be overweight [5]. Recent studies in Britain have indicated that females between the ages 12 and 16 have a higher BMI than males of the same age by $1.0 \mathrm{~kg} / \mathrm{m}^{2}$ on average [6]. Hemoglobin, abbreviated $\mathrm{Hb}$ or $\mathrm{Hgb}$, is the iron-containing oxygen-transport metalloprotein in the red blood cells (erythrocytes) of almost all vertebrates [7] (the exception being the fish family Channichthyidae [8]) as well as the tissues of some invertebrates. Hemoglobin in the blood carries oxygen from the lungs or gills to the rest of the body (i.e. the tissues). There it releases the oxygen to permit aerobic respiration to provide energy to power the functions of the organism in metabolism [9]. Hemoglobin has an oxygen-binding capacity of $1.34 \mathrm{~mL} \mathrm{O}_{2}$ per gram [10], which increases the total blood oxygen capacity seventy-fold compared to dissolved oxygen in blood. The mammalian hemoglobin molecule can bind (carry) up to four oxygen molecules [11]. Hemoglobin is involved in the transport of other gases: It carries some of the body's respiratory carbon dioxide (about 20 - 25\% of the total [12]) as carbaminohemoglobin, in which $\mathrm{CO}_{2}$ is bound to the heme protein. Hemoglobin is also found outside red blood cells and their progenitor lines [13]. Other cells that contain hemoglobin include macrophages, alveolar cells, lungs, retinal pigment epithelium, mesangial cells in the kidney, endometrial cells [14]. In these tissues, hemoglobin has a non-oxygen-carrying function as an antioxidant and a regulator of iron metabolism [15]. Hemoglobin and hemoglobin-like molecules are also found in many invertebrates, fungi, and plants [16]. In these organisms, hemoglobin may carry oxygen, or they may act to transport and regulate other small molecules and ions such as carbon dioxide, nitric oxide, hydrogen sulfide and sulfide. 


\section{Aim of the Study}

The aim of this research is studying the relationship between $\mathrm{Hb}$ and BMI.

\section{Patients and Methods}

The study carried out in the out patients' department and hematological laboratory of Al Sadir Teaching Hospital. A patient who visit the outpatient department who had $\mathrm{Hb}$ request from the outpatient physicians were asked to participate in the study; the anthropometric measurements (body weight and height) takes place in the nutrition clinic in that department. Then, the researcher participates in the procedure of $\mathrm{Hb}$ measurement in the hema- tology laboratory. All the information regarding age, sex, weight, height, and $\mathrm{Hb}$ level, were written in a paper sheet then transferred to excel sheet were the data analyses performed. The body electronic weight scale (seca scale) and the height is measured by height (seca scale). The BMI calculated from these two variables according to this equation BMI $=\mathrm{Wt} . /(\mathrm{Ht} \text {. })^{2}$. The SI unit is $\mathrm{kg} / \mathrm{m}^{2}$. Then an intravenous blood specimens taken from the patient (at least 2CC) in EDTA tube. The tube was put the tube in the complete blood count device (sysmax; XT-2000i). The result was expressed in paper sheet.

\section{Results}

\begin{tabular}{|l|c|c|c|c|c|c|}
\hline \multicolumn{1}{|c|}{ Ranges } & Under Weight & Normal Weight & Over Weight & Class 1 Obesity & Class 2 Obesity & Class 3 Obesity \\
\hline No. of individuals & 7 & 16 & 7 & 15 & 15 & 19 \\
\hline Hb normal & 5 & 6 & 4 & 6 & 6 & 9 \\
\hline Hb decreasing & 2 & 10 & 3 & 9 & 13 \\
\hline Ages & $18-25$ & $18-35$ & $18-27$ & $19-50$ & $18-57$ & $24-65$ \\
\hline Percent of Hb normal & $71.43 \%$ & $37.50 \%$ & $57.14 \%$ & $40 \%$ & $40.00 \%$ & $31.58 \%$ \\
\hline
\end{tabular}

Table 1: The relationship between weights HB and age in 80 females which about $(74.07 \%)$ of the total specimens.

\begin{tabular}{|l|c|c|c|c|c|c|}
\hline \multicolumn{1}{|c|}{ Ranges of BMI } & Under Weight & Normal Weight & Over Weight & Class 1 Obesity & Class 2 Obesity & Class 3 Obesity \\
\hline No. of individuals & 4 & 13 & 6 & 3 & 2 & 0 \\
\hline Hb normal & 2 & 6 & 1 & 3 & 1 & 0 \\
\hline Hb decreasing & 2 & 7 & 5 & 0 & 1 & 0 \\
\hline Ages & $19-23$ & $20-29$ & $23-30$ & $19-24$ & $27-39$ & 0 \\
\hline Percent of Hb normal & $50 \%$ & $46.15 \%$ & $16.67 \%$ & $100 \%$ & $50 \%$ & 0 \\
\hline
\end{tabular}

Table 2: The relationship between weights HB and age for 28 males which about (25.92\%) of the total specimens.

\begin{tabular}{|l|c|c|c|c|c|c|}
\hline \multicolumn{1}{|c|}{ Ranges of BMI } & Under Weight & Normal Weight & Over Weight & Class 1 Obesity & Class 2 Obesity & Class 3 Obesity \\
\hline No. of individuals & 11 & 29 & 13 & 18 & 17 & 19 \\
\hline Hb normal & 7 & 12 & 5 & 9 & 7 & 6 \\
\hline Hb decreasing & 4 & 17 & 10 & 9 & 10 & 13 \\
\hline Ages & $18-25$ & $18-35$ & $18-30$ & $19-50$ & $18-57$ & $24-65$ \\
\hline Percent of Hb normal & $63.64 \%$ & $41.38 \%$ & $38.46 \%$ & $50 \%$ & $41.18 \%$ & $31.58 \%$ \\
\hline
\end{tabular}

Table 3: The relationship between weights HB and age for all specimens (male and female) where there are (108) specimens.

\section{Discussion and Conclusion}

There is decreasing in the $\mathrm{Hb}$ of the obesity in all classes and this is because the obese people may include more carbohydrates or fats in their diet rather than nutrients dense food rich in vitamins and minerals i.e. more macronutrients and less in micronutrients, in the research there was number of female specimens more than male specimens the reason about this is may be that females care about their body health more than males since all specimens have been taken from the hospital, and in female specimens observed that as the BMI increase there is a drop in $\mathrm{Hb}$ this is probably the result of the unhealthy food that women eat and also that the number of females increases as we go to obesity classes because a large 
number of females in our country are unemployed and thus they have less work and movement in their days and most of their time is spared at home where there is less activities to do and this is in reverse for the men which are mostly have normal weight for the opposite reason compared to women.

\section{Bibliography}

1. Nuttall FQ. "Body Mass Index: Obesity, BMI, and Health A Critical Review”. Nutrition Today 3 (2015): 117-128.

2. Janghorbani M., et al. "First Nationwide Survey of Prevalence of Overweight, Underweight, and Abdominal Obesity in Iranian Adults". Obesity 15 (2007): 2797-2808.

3. Al-Nuaimt A., et al. "High prevalence of overweight and obesity in Saudi Arabia". International Journal of Obesity 20 (1996): 547-552.

4. Von Hippel PT., et al. "The Effect of School on Overweight in Childhood: Gain in Body Mass Index During the School Year and During Summer Vacation". American Journal of Public Health 97 (2007): 696-702.

5. Maynard LM., et al. "Maternal Perceptions of Weight Status of Children”. Pediatrics 111 (2003): 1226-1231.

6. Saxena S., et al. "Ethnic group differences in overweight and obese children and young people in England: cross sectional survey". Archives of Disease in Childhood 89 (2004): 30-36.

7. Dibley MJ., et al. "Interpretation of Z-score anthropometric indicators derived from the international growth reference". The American Journal of Clinical Nutrition 1 (1987): 749-762.

8. Sidell BD. "When bad things happen to good fish: the loss of hemoglobin and myoglobin expression in Antarctic icefishes". Journal of Experimental Biology 209 (2006): 1791-1802.

9. Weed RI. "Is hemoglobin an essential structural component of human erythrocyte membranes?". Journal Clinical Investigation 42 (1963): 581-588.

10. Dominguez ED., et al. "Equality of the in vivo and in vitro oxygen-binding capacity of haemoglobin in patients with severe respiratory disease". British Journal of Anaesthesia 53 (1981): 1325-1328

11. Asterios S., et al. "Heme as key regulator of major mammalian cellular functions: Molecular, cellular, and pharmacological aspects". Pharmacology and Therapeutics 111 (2006): 327-345.
12. Pelster B. "The Generation of Hyperbaric Oxygen Tensions in Fish". Physiology News Physiology Science 16 (2001): 287-291.

13. Epstein FH and Hsia CW. "Respiratory Function of Hemoglobin”. New England Journal of Medicine 338 (1998): 239-247.

14. Saha D., et al. "Hemoglobin Expression in Nonerythroid Cells: Novel or Ubiquitous?". International Journal Inflammation (2014) : 1-8.

15. Biagioli M., et al. "Unexpected expression of alpha- and betaglobin in mesencephalic dopaminergic neurons and glial cells". Proceedings of the National Academy of Sciences of the United States of America106 (2009): 15454-15459.

16. Weber RE and Vinogradov SN. "Nonvertebrate hemoglobins: functions and molecular adaptations". Physiolgical Review 81 (2001): 569-628.

\section{Assets from publication with us}

- Prompt Acknowledgement after receiving the article

- Thorough Double blinded peer review

- Rapid Publication

- Issue of Publication Certificate

- High visibility of your Published work

Website: https://www.actascientific.com/

Submit Article: https://www.actascientific.com/submission.php Email us: editor@actascientific.com

Contact us: +919182824667 